\title{
An electrochemiluminescence sensing for DNA glycosylase assay with enhanced host-guest recognition technique based on $\alpha$-cyclodextrin functionalized gold/silica cell-shell nanoparticles
}

Tingting Zhang, Huimin Zhao*, Xie Quan, Shuo Chen

Key Laboratory of Industrial Ecology and Environmental Engineering (Ministry of Education, Dalian 116024, China), School of Environmental Science and Technology, Dalian University of Technology, Dalian 116024, China

* Corresponding author. Tel.: +86411 84706263; fax: +86 41184706263.

E-mail address: zhaohuim@dlut.edu.cn

Abstract

An electrochemiluminescence (ECL) sensing for sensitive assaying of active DNA glycosylase was developed using the enhanced host-guest recognition technique. The $\alpha$-cyclodextrin was selected as the host molecule which captured the guest-labeled ECL probe to the surface of electrode by the host-guest recognition. The ECL probe can be protected from the digestion of exonuclease I (Exo I) and exonuclease III (Exo III) with the presence of the target enzyme human 8-oxoguanine DNA glycosylase 1 (hOGG 1), resulting in the ECL emission intensity was correlated with the quantity of hOGG 1 . The $\alpha$-cyclodextrin functionalized gold/silica $\left(\mathrm{Au} / \mathrm{SiO}_{2}\right)$ cell-shell nanoparticles was prepared to enhance the host-guest recognition sensitivity. Because of the increased recognition sites provided by $\alpha$-cyclodextrin functionalized $\mathrm{Au} / \mathrm{SiO}_{2}$ cell-shell nanoparticles, the nanoparticle-modified electrode displayed a high capacity for the guest ECL probe, and four fold enhancement of the ECL signals was 
achieved. The as-prepared ECL sensing exhibits excellent analytical property for the detection of hOGG 1 in the linear range of 2-100 $\mathrm{U} \mathrm{mL}^{-1}$ with a detection limit of $0.225 \mathrm{U} \mathrm{mL}^{-1}(\mathrm{~S} / \mathrm{N}=3)$. Interference tests show that the ECL intensity of the interferents human apurinic/apyrimidinic endonuclease (APE 1), T4 endonuclease V (T4 PDG) and endonuclease III (Endo III) is within 36.5 to $44.7 \%$ of that of hOGG 1. The ECL sensing exhibits long-term stability with a relative standard deviation (RSD) of $1.6 \%$ for 16 cycles of continuous potential scans, and the life time of the ECL sensing is up to 20 days. The obtained results in this study indicate that the proposed ECL sensing possesses high sensitivity, specificity and stability and provides a powerful tool for assaying hOGG 1 activity.

Keyword: DNA glycosylase; electrochemiluminescence; $\alpha$-cyclodextrin; gold/silica cell-shell nanoparticles

\section{Introduction}

Oxidative stresses from the environment, such as ionizing radiation or chemical genotoxic compounds, can generate oxidative damage of DNA. Oxidative damage of DNA and its reparation are vital to the maintenance of genomic integrity and regulation of gene expression for living organisms [1]. Oxidative damage of DNA can lead to several types of DNA modifications. A major DNA-base modified products is 8-oxo-7,8-dihydroguanine (8-oxoguanine, 8-oxo-dGor 8-OHdG) [2]. Fortunately, both modified product and DNA lesions can be repaired using base excision repair [3]. DNA glycosylase in the human body was named human 8-oxoguanine DNA glycosylase 1 (hOGG 1) and can recognize and remove 8-oxo-dG from oxidatively 
damaged DNA $[4,5]$. The aberrant expression of hOGG 1 has profound implications in many serious diseases such as cancers [6], Parkinson's disease [7], and autoimmune diseases [8]. Therefore, the activity of hOGG 1 as significant biomarkers for these diseases, i.e., its activity assay, has great value for clinical diagnosis and treatment of these diseases [9].

The most common methods to assay the activity of hOGG 1 are ${ }^{32} \mathrm{P}$-labeled fragments using gel electrophoresis [10], matrix-assisted laser desorption/ionization time-of-flight mass spectrometry (MALDI-TOF-MS) [11], and liquid chromatography-mass spectrometric (LC-MS) [12]. These methods indirectly investigate the activity of hOGG 1 by quantifying the amount of the released base or the amount of AP site strand. These indirect quantification methods are difficult to realize on-line detection. In addition to these methods, other methods such as paramagnetic beads [13] and molecular beacons [14] were reported for assaying the activity of DNA glycosylase. However, these methods are demanding in experimental conditions and require professional operation, which is not conducive to popularization and application.

The electrochemiluminescence (ECL) sensing technology has received particular attention mostly because of its high sensitivity, good controllability and fast response. In recent years, several new ECL sensing strategies have been reported to assay the activity of DNA methyltransferase $[15,16]$. These methods can realize selective detection of DNA methyltransferase in certain ranges of concentrations. However, the probes to selectively recognize DNA methyltransferase are directly modified on the 
electrode surface, which limits further improvement for their sensitivities.

Recently, because of its excellent ability of signal amplification, gold/silica $\left(\mathrm{Au} / \mathrm{SiO}_{2}\right)$ core-shell nanoparticles, which comprise a gold core coated with a silica shell, is widely used in detection and sensing fields [17,18]. In addition, it also has robust chemical stability, uniform and biocompatibility of the $\mathrm{SiO}_{2}$ shell coating, and ease of surface functionalization. Furthermore, as a type of molecular recognition technologies, the host-guest recognition is defined as the supramolecular noncovalent interaction between the "host" and "guest" molecules, which plays an important role in DNA sensing [19]. In the recognition process, cyclodextrins (CDs) are used as the host molecule, which are toroidal in shape with a hydrophobic cavity and a hydrophilic exterior, and their unique "cage" structures enable them and their derivatives to express outstanding recognition ability to encapsulate the guest molecules. Therefore, it is predictable that several advantages may be endowed on sensors with $\mathrm{CDs}$ that is modified on the surface of $\mathrm{Au} / \mathrm{SiO}_{2}$ core-shell nanoparticles, such as increased recognition sites of the host and enhanced the recognition sensitivity and the possibility of designing a great variety of three-dimensional arrangements on the electrode surfaces [20].

In this work, we used the enhanced host-guest recognition based on $\alpha$-CD functionalized $\mathrm{Au} / \mathrm{SiO}_{2}$ cell-shell nanoparticles to assay the activity of hOGG 1 . As illustrated in Scheme1, two key components were used for this ECL sensing. One component was an $\alpha-\mathrm{CD}$ functionalized $\mathrm{Au} / \mathrm{SiO}_{2}$ cell-shell nanoparticles, which modified the platinum electrode (noted as $\mathrm{Pt} / \mathrm{Au} / \mathrm{SiO}_{2} / \alpha-\mathrm{CD}$ ) and had special 
recognition ability to the "guest" molecules because of the presence of $\alpha-C D$. The other component was a guest-labeled ECL probe, which consisted of the Ru(bpy) ${ }_{2}^{3+}$ compound, single-walled carbon nanotubes (SWNTs) and double-stranded DNA (dsDNA) (noted as RuSD) [21]. The SWNTs and Ru(bpy) ${ }_{2}{ }^{3+}$ compound were decorated with the dsDNA, which contained an enzyme-reactive nucleotide (8-oxo-dG) and a dabcyl modified at 3' terminus in one of the two strands. The dabcyl molecule was a typical guest of $\alpha-C D$; thus, RuSD was captured using the $\mathrm{Pt} / \mathrm{Au} / \mathrm{SiO}_{2} / \alpha-\mathrm{CD}$ electrode during the sensing procedure. In the presence of the target enzyme hOGG 1, the lesion base 8-oxo-dG was irreversibly captured by hOGG 1 because the reducing agent $\mathrm{NaBH}_{3} \mathrm{CN}$ intercepted the hydrolysis of a Schiff base intermediate [22]. The terminal protection was created by the trapped enzyme protein for exempting the digestion of exonuclease I (Exo I) and exonuclease III (Exo III) to RuSD [23,24], which maintained the quantity of RuSD on the surface of the electrode with the ECL emission. In contrast, the inexistence target enzyme electrode-captured RuSD was incubated with Exo I and III, and the dsDNA of RuSD was digested, which indicates that the quantity of RuSD on the electrode surface was greatly reduced; as a result, the ECL emission intensity of the sensor decreased. Obviously, the quantity of RuSD dynamically depended on the amount of active enzymes, which allows the quantitative assay of the enzyme activity.

\section{Experimental}

\subsection{Reagents and chemicals}

hOGG1, exonuclease I (Exo I), exonuclease III (Exo III), T4 endonuclease V 
(T4PDG), human apurinic/apyrimidinic endonuclease (APE 1) and endonuclease III (Endo III) were purchased from New England Biolabs (Beijing) LTD. (Beijing, China). Chlorauric acid $\left(\mathrm{HAuCl}_{4} \cdot 3 \mathrm{H}_{2} \mathrm{O}\right)$, tetraethoxysilane (TEOS), poly (vinylpyrrolidone) (PVP) and trisodium citrate $\left(\mathrm{C}_{6} \mathrm{H}_{5} \mathrm{Na}_{3} \mathrm{O}_{7} \cdot 2 \mathrm{H}_{2} \mathrm{O}\right)$ were bought from Xilong Chemical Co., Ltd. (Guangdong, China). Mono-6-O-(p-toluenesulfonyl)- $\alpha$-cyclodextrin (6-TsO- $\alpha-\mathrm{CD}), \quad$ tris $\quad(2,2$ '-bipyridyl) ruthenium (II) chloride hexahydrate $\left[\mathrm{Ru}(\mathrm{bpy})_{2} \mathrm{Cl}_{2} \bullet 6 \mathrm{H}_{2} \mathrm{O}\right]$, N,N'-dicyclohexylcarbodiimide (DCCI), 2,2'-bipyridine-4,4'-dicarboxylic acid, sodium hexafluorphosphate $\left(\mathrm{NaPF}_{6}\right)$ and (3-aminopropyl)-trimethoxysilane (APTES) were supplied by J\&K Scientific Ltd. (Beijing, China). Ethyl-3-(dimethyl aminopropyl) carbodiimide (EDC) and N-hydroxysuccinimide (NHS) were purchased from Sigma (America). Tripropylamine (TPrA) and sodium cyanoborohydride $\left(\mathrm{NaBH}_{3} \mathrm{CN}\right.$ ) were provided by Aladdin (Shanghai, China). N,N-dimetbylformamide (DMF) was bought from Tianjin Fuyu Fine Chemical Co., Ltd. (Tianjin, China). SWNTs were obtained from Shenzhen Nanotechnology Port. Co., Ltd. (Shenzhen, China). Phosphate buffer solution (PBS, $0.1 \mathrm{~mol} \mathrm{~L}^{-1}, \mathrm{pH}=7.5$ ) was prepared by mixing the stock solutions of $\mathrm{Na}_{2} \mathrm{HPO}_{4}\left(0.1 \mathrm{~mol} \mathrm{~L}^{-1}\right)$ and $\mathrm{NaH}_{2} \mathrm{PO}_{4}(0.1 \mathrm{~mol} \mathrm{~L}-1)$. Ultrapure water, which was purified using a Millipore water system (resistivity $>18.0 \mathrm{M} \Omega \mathrm{cm}^{-1}$, Laikie Instrument Co., Ltd., Shanghai, China), was used throughout the experiments. The dabcyl-labeled double-stranded DNA (dsDNA) were obtained from Takara Biotechnology (Dalian) Co., Ltd. (Dalian, China) with HPLC purification $\left({ }^{\text {oxo }} \mathrm{G}\right.$ is 8-oxo-dG). 
Dabcyl-labeled dsDNA:

5'-NH ${ }_{2}-(\mathrm{CH})_{6}$-GCACATCAGTT ${ }^{\mathrm{oxo}}$ GAGCTCC-DABCYL-3'

5'-GGAGCTCAACTGATGTGC-3'

\subsection{Apparatus}

The ECL emission was detected using a MPI-B multi-parameter chemiluminescence analysis test system (Xi'an Remax Analysis Instrument Co., Ltd., Xi'an, China) with a three-electrode system, which consisted of a bare or modified Pt electrode (1 mm-diameter) as the working electrode, the silver-silver chloride electrode $(\mathrm{Ag} / \mathrm{AgCl}$, saturated $\mathrm{KCl})$ as the reference electrode and a $\mathrm{Pt}$ wire as the auxiliary electrode. Unless noted, the photomultiplier tube (PMT) was $600 \mathrm{~V}$. Electrochemical impedance spectroscopy (EIS) was performed on a PARSTAT 2273 advanced electrochemical system (Princeton Applied Research, America). Fourier transform infrared spectrometry (FT-IR) was acquired with a Bruker VERTEX 70 FTIR spectrometer, which was equipped with the resolution of $4 \mathrm{~cm}^{-1}$ with a DTGS detector in the range of $4000-600 \mathrm{~cm}^{-1}$ (Germany). The sample morphology was observed using transmission electron microscopy (TEM) (FEI Tecnai G2 20, America). UV-visible spectra were performed on a Jasco V-550 spectrometer (Japan).

\subsection{Synthesis of $\alpha$-cyclodextrin functionalized $\mathrm{Au} / \mathrm{SiO}_{2}$ core-shell nanoparticles}

Preparation of $\mathrm{Au} / \mathrm{SiO}_{2}$ core-shell nanoparticles: The $\mathrm{Au} / \mathrm{SiO}_{2}$ core-shell nanoparticles were synthesized using Stöber process in accordance to the literature [25]. The AuNPs were synthesized through the seeded growth and synthesis process according to N.G. Bastúset al. [26]. The AuNPs were activated by poly 
(vinylpyrrolidone) (PVP). Then, the PVP-attached AuNPs was added to the mixture of ammonia and ethanol $\left(\mathrm{V}_{\text {ammonia }}=0.8 \mathrm{~mL}, \mathrm{~V}_{\text {ethanol }}=29.2 \mathrm{~mL}\right)$ under magnetic stirring. The mixture of TEOS $(0.2 \mathrm{~mL})$ and ethanol $(19.8 \mathrm{~mL})$ was injected into this mixture within $12.5 \mathrm{~h}$. After magnetic stirring for 12 hours, the synthesized $\mathrm{Au} / \mathrm{SiO}_{2}$ core-shell nanoparticles were collected by centrifuging.

The formation of $\alpha$-cyclodextrin functionalized $\mathrm{Au} / \mathrm{SiO}_{2}$ core-shell nanoparticles: The synthesis process (shown in Scheme 2) was performed according to the previous literature [27]. The as-prepared $\mathrm{Au} / \mathrm{SiO}_{2}$ nanoparticles were dispersed in ethanol (40.0 $\mathrm{mL})$. The APTES were used to modify the silica surface with amine groups. Then the amine-functionalized $\mathrm{Au} / \mathrm{SiO}_{2}$ core-shell nanoparticles $(20 \mathrm{mg})$ and $10 \mathrm{mg}$ 6-TsO- $\alpha-\mathrm{CD}$ were re-dispersed in $10 \mathrm{~mL}$ of $0.1 \mathrm{~mol} \mathrm{~L}^{-1} \mathrm{PBS}(\mathrm{pH}$ 8). The secondary aldimine linkages was formed on the surface of the nanoparticles after magnetic stirring for 3 hours. Then, $100 \mathrm{mg} \mathrm{NaBH}_{3} \mathrm{CN}$ was added to complete the reductive alkylation reaction. Finally, the $\alpha$-cyclodextrin functionalized $\mathrm{Au} / \mathrm{SiO}_{2}$ core-shell nanoparticles were obtained by centrifugation (noted as $\mathrm{Au} / \mathrm{SiO}_{2} / \alpha-\mathrm{CD}$ ).

\subsection{Preparation of ECL probe: RuSD}

Synthesis of $\quad \mathrm{Ru}(\mathrm{bpy})_{2}{ }^{3+} \quad$ compound-Ru bis(2,2'-bipyridine $)$ (2,2'-bipyridine-4,4'-dicarboxylic acid) N-hydroxysuccinimide ester $\left[\mathrm{Ru}(\mathrm{bpy})_{2}(\mathrm{dcbpy}) \mathrm{NHS}\right]: \quad$ First, $\quad \mathrm{Ru} \quad$ bis(2,2'-bipyridine) (2,2'-bipyridine-4,4'-dicarboxylicacid) bis(hexafluoropropylene phosphor) ([Ru(bpy $\left.\left.)_{2}(\mathrm{dcbpy})\left(\mathrm{PF}_{6}\right)_{2}\right]\right)$ was synthesized according to the previous literatures [28]. Second, Ru(bpy $)_{2}$ (dcbpy)NHS was synthesized as follows [29]: $0.3 \mathrm{~g}$ DCCI and $0.2 \mathrm{~g}$ 
NHS were dissolved in $1.5 \mathrm{~mL}$ DMF in an ice bath. Then, $1 \mathrm{~mL}$ of DMF containing $0.2 \mathrm{~g} \mathrm{Ru}(\mathrm{bpy})_{2}(\mathrm{dcbpy})\left(\mathrm{PF}_{6}\right)_{2}$ was added, and the mixture was magnetically stirred for $7 \mathrm{~h}$. The formed mixture was vacuum-dried to obtain Ru(bpy) ${ }_{2}(\mathrm{dcbpy}) \mathrm{NHS}$. These processes were performed in dark.

Preparation of RuSD: RuSD was prepared by a modified method described in the literatures [30,31]. $\mathrm{HNO}_{3}$ and $\mathrm{HNO}_{3} / \mathrm{H}_{2} \mathrm{SO}_{4}$ mixture were used to purify and shorten SWNTs, respectively. The as-prepared SWNTs $(1 \mathrm{mg})$ was dispersed in $0.2 \%$ DMF. Then, NHS and EDC were added to activate SWNTs, under ultrasonic condition. The $\mathrm{pH}$ value of the mixture was adjusted to 7.0 with $0.1 \mathrm{~mol} \mathrm{~L}^{-1}$ hydrochloric acid solution and continuingly sonicated for $10 \mathrm{~h}$ [32]. Then, we adjusted the $\mathrm{pH}$ value to 8.5. Following this step, $50 \mu \mathrm{L}$ dabcyl-labeled dsDNA $\left(100 \mu \mathrm{mol} \mathrm{L} \mathrm{L}^{-1}\right)$ and $11 \mathrm{mg}$ $\mathrm{Ru}(\mathrm{bpy})_{2}$ (dcbpy)NHS were added into the above suspension. The mixture was stirred over night, then centrifuged and washed several times with $0.5 \mathrm{~mol} \mathrm{~L}^{-1} \mathrm{NaCl}$. The resulting solution was allowed to stand at $4{ }^{\circ} \mathrm{C}$ overnight, and the final supernatant fractions were RuSD. Finally, the prepared RuSD were diluted with $0.01 \mathrm{~mol} \mathrm{~L}^{-1} \mathrm{PBS}$ (pH 7.5) for use.

\subsection{Preparation of the ECL electrode}

Prior to modification, the Pt electrode ( $1 \mathrm{~mm}$-diameter) was mildly polished with $0.7 \mu \mathrm{m}$ and $50 \mathrm{~nm}$ alumina slurry and ultrasonically washed in ethanol and ultrapure water for a few minutes, respectively. $1 \mu \mathrm{L}$ of $\mathrm{Au} / \mathrm{SiO}_{2} / \alpha-\mathrm{CD}$ nanoparticles suspension was dropped on the pretreated $\mathrm{Pt}$ electrode (noted as $\mathrm{Pt} / \mathrm{Au} / \mathrm{SiO}_{2} / \alpha-\mathrm{CD}$ ) and naturally dried at room temperature. $1 \mu \mathrm{L}$ of the RuSD solution was dropped on 
the surface of $\mathrm{Pt} / \mathrm{Au} / \mathrm{SiO}_{2} / \alpha-\mathrm{CD}$ electrode and allowed to stand for $2 \mathrm{~h}$ to capture RuSD onto the electrode with the host-guest recognition. The electrode was rinsed with $0.01 \mathrm{~mol} \mathrm{~L}{ }^{-1} \mathrm{PBS}$ ( $\mathrm{pH} 7.5$ ) to remove the loosely bound RuSD, and the ECL electrode was obtained and noted as $\mathrm{Pt} / \mathrm{Au} / \mathrm{SiO}_{2} / \alpha-\mathrm{CD} / \mathrm{RuSD}$ (the entire procedure is presented in Scheme 3).

\subsection{Assay of hOGG 1}

In summary, the $\mathrm{Pt} / \mathrm{Au} / \mathrm{SiO}_{2} / \alpha-\mathrm{CD} / \mathrm{RuSD}$ electrode was immersed in a $50 \mu \mathrm{L}$ of $10 \mathrm{mmol} \mathrm{L}{ }^{-1}$ Tris- $\mathrm{HCl}$ solutions, which contained $100 \mu \mathrm{g} \mathrm{mL} \mathrm{H}^{-1} \mathrm{BSA}, 100 \mathrm{mmol} \mathrm{L}^{-1}$ $\mathrm{NaBH}_{3} \mathrm{CN}$ and various concentrations of hOGG 1 . The reaction was performed at $37{ }^{\circ} \mathrm{C}$ for $2 \mathrm{~h}$ in a water bath; then, the mixture was heated to $90{ }^{\circ} \mathrm{C}$ for 5 min (the electrode noted as $\left.\mathrm{Pt} / \mathrm{Au} / \mathrm{SiO}_{2} / \alpha-\mathrm{CD} / \mathrm{RuSD} / \mathrm{hOGG} 1\right)$. Subsequently, $0.2 \mathrm{U}_{\mu} \mathrm{L}^{-1}$ Exo I and $1 \mathrm{U} \mu \mathrm{L}^{-1}$ Exo III were added in the mixture and continued to react for $30 \mathrm{~min}$ at

$37{ }^{\circ} \mathrm{C}$. Finally, the electrode was removed from the mixture solution and rinsed with $0.01 \mathrm{~mol} \mathrm{~L}^{-1} \mathrm{PBS}(\mathrm{pH} 7.5)$. The modified electrode was scanned in $0.1 \mathrm{~mol} \mathrm{~L}^{-1} \mathrm{PBS}$ ( $\mathrm{pH}$ 7.5), which contained $0.1 \mathrm{~mol} \mathrm{~L} \mathrm{~L}^{-1} \mathrm{TPrA}$. The PMT voltage was maintained at 600 $\mathrm{V}$, and the potential range was $0.8-1.2 \mathrm{~V}$ with a scan rate of $0.1 \mathrm{~V} \mathrm{~s}^{-1}$.

\section{Results and Discussion}

\subsection{Characterization of $\alpha$-cyclodextrin functionalized $\mathrm{Au} / \mathrm{SiO}_{2}$ core-shell}

\section{nanoparticles}

To verify the successful synthesis of $\alpha$-CD functionalized $\mathrm{Au} / \mathrm{SiO}_{2}$ core-shell nanoparticles, the nanoparticles were characterized using FT-IR spectroscopy and TEM. Fig. 1A presented the FT-IR spectra of the 6-TsO- $\alpha-\mathrm{CD}$ (curve a), $\mathrm{Au} / \mathrm{SiO}_{2}$ 
(curve b) and $\mathrm{Au} / \mathrm{SiO}_{2} / \alpha-\mathrm{CD}$ (curve c). The characteristic peaks of $6-\mathrm{TsO}-\alpha-\mathrm{CD}$ (curve a) were at 957, 1030,1077, $1158 \mathrm{~cm}^{-1}$ [33]. The characteristic band at 1030 $\mathrm{cm}^{-1}$ was assigned to the stretching vibration of $\mathrm{v}(\mathrm{C}-\mathrm{O}-\mathrm{C})$; the band at $1158 \mathrm{~cm}^{-1}$ originated from the coupled $v(\mathrm{C}-\mathrm{C} / \mathrm{C}-\mathrm{O})$ stretch vibration [34,35]. The FT-IR spectrum of $\mathrm{Au} / \mathrm{SiO}_{2}$ (curve b) shows a band at $1085 \mathrm{~cm}^{-1}$, which corresponded to the stretching vibration of the Si-O-Si bond in oxygen-silica tetrahedron [36]. Both characteristic bands of 6-TsO- $\alpha-\mathrm{CD}\left(1030 \mathrm{~cm}^{-1}\right)$ and $\mathrm{Au} / \mathrm{SiO}_{2}\left(1085 \mathrm{~cm}^{-1}\right)$ were observed in the spectrum of $\mathrm{Au} / \mathrm{SiO}_{2} / \alpha-\mathrm{CD}$ (curve c). In addition, the band at 1385 $\mathrm{cm}^{-1}$ was observed, which was attributed to the $\mathrm{C}=\mathrm{N}$ groups that were generated using the reductive alkylation. Fig. $1 \mathrm{~B}$ shows the TEM image of $\mathrm{Au} / \mathrm{SiO}_{2}$ core-shell nanoparticles. These results indicate that $\mathrm{Au} / \mathrm{SiO}_{2} / \alpha-\mathrm{CD}$ was successfully synthesized in this work. The diameters of $\mathrm{Au} / \mathrm{SiO}_{2}$ core-shell nanoparticles were found over the range of 40-50 $\mathrm{nm}$, and the configuration appeared spherical and monodispersed. After modified with 6-TsO- $\alpha-\mathrm{CD}$ (Fig. 1C), the basic structure and monodispersity of the nanoparticles were maintained.

\subsection{Characterization of the ECL probe: RuSD}

Fig. 2A shows the UV-Vis absorption spectra of SWMTs (curve a), dabcyl-labeled dsDNA (curve b), Ru(bpy)2(dcbpy)NHS (curve c) and RuSD (curve d). A characteristic absorption peak of dabcyl-labeled dsDNA appears at $260 \mathrm{~nm}$ (curve b). The absorption spectrum of Ru(bpy)2(dcbpy)NHS (curve c) exhibits the characteristic peaks at $457 \mathrm{~nm}$ and $287 \mathrm{~nm}$, which were assigned to the metal-to-ligand charge-transfer band. In the UV-Vis absorption spectrum of RuSD 
(curve d), the absorption peaks at $457 \mathrm{~nm}$ and $287 \mathrm{~nm}$ correspond to the characteristic peaks of $\mathrm{Ru}(\mathrm{bpy}) 2(\mathrm{dcbpy}) \mathrm{NHS}$; the absorption peak at $257 \mathrm{~nm}$ was slightly blue-shifted compared to the characteristic peaks of DNA at $260 \mathrm{~nm}$, which may be attributed to the amido bond that was formed by linking the carbonyl of SWNTs with the amido of DNA [37]. This result strongly indicates that Ru(bpy)2(dcbpy)NHS and dabcyl-labeled dsDNA were conjugated to SWNTs. Fig. 2B shows the TEM image of SWNTs. The surfaces of SWNTs were smooth and uniform. Obviously, some aggregated structures (as designated) appeared on the surface of SWNTs after conjugated with dabcyl-labeled dsDNA and Ru(bpy) ${ }_{2}$ (dcbpy)NHS (Fig. 2C). These results proved that the RuSD was successfully prepared.

\subsection{ECL behaviors and EIS characterization of the ECL electrode}

The ECL behaviors of the ECL electrode were recorded in $0.1 \mathrm{~mol} \mathrm{~L}^{-1} \mathrm{PBS}(\mathrm{pH}$ 7.5), which contained $0.1 \mathrm{~mol} \mathrm{~L}{ }^{-1} \mathrm{TPrA}$, and the ECL electrode was scanned from 0.8 $\mathrm{V}$ to $1.2 \mathrm{~V}$ (Fig. 3A). The ECL intensity was attributed to the reaction of the $\mathrm{Ru}(\mathrm{bpy}) 3^{2+}-\mathrm{TPrA}$ system in this study. Because of the absence of Ru(bpy) ${ }^{2+}$ in the reaction system, there was almost no ECL emission of the Pt electrode (curve a), $\mathrm{Pt} / \alpha-\mathrm{CD}$ (curve b) and $\mathrm{Pt} / \mathrm{Au} / \mathrm{SiO}_{2} / \alpha-\mathrm{CD}$ (curve c). The ECL intensity of the $\mathrm{Pt} / \alpha-\mathrm{CD} / \mathrm{RuSD}$ electrode (curve d) obviously increased compared with that of the above electrodes. To recognize RuSD using $\alpha$-CD through the host-guest recognition, the reaction of the $\mathrm{Ru}(\mathrm{bpy})_{3}{ }^{2+}-\mathrm{TPrA}$ system was activated. The ECL intensity of $\mathrm{Pt} / \mathrm{Au} / \mathrm{SiO}_{2} / \alpha-\mathrm{CD} / \mathrm{RuSD}$ (curve e) was approximately four times higher than that of $\mathrm{Pt} / \alpha-\mathrm{CD} / \mathrm{RuSD}$. The host-guest recognition was greatly enhanced because of the 
important roles of $\alpha$-cyclodextrin functionalized $\mathrm{Au} / \mathrm{SiO}_{2}$ core-shell nanoparticles, where the $\mathrm{Au} / \mathrm{SiO}_{2}$ core-shell nanoparticles increased the recognition sites of the host.

EIS is an effective tool to investigate the interfacial properties of the modified electrodes. Fig. 3B shows the EIS figures of different electrodes, and they are fitted using an equivalent circuit (inset in Fig. 3B). The equivalent circuit includes four parameters. The ohmic resistance of the electrolyte solution $\left(\mathrm{R}_{\mathrm{s}}\right)$ is the intersection of the curve at the real part $Z^{\prime}$ in the high frequency, the Faradic charge transfer resistance $\left(\mathrm{R}_{\mathrm{ct}}\right)$ corresponds to the semicircle at high frequencies, the Warburg impedance (W) is the slope of the curves at a low frequency range, and C denotes the double-layer capacitance $[38,39]$. It is well known that $\mathrm{R}_{\mathrm{ct}}$ controls the interfacial electron-transfer rate of the redox probe between the solution and the electrode. Obvious differences in Faradic charge transfer resistance were acquired for the electrodes at different stages of modification. The resistance of bare Pt electrode (curve c) was $476.5 \Omega$. After modified with $\mathrm{Au} / \mathrm{SiO}_{2}$ nanoparticles, $\mathrm{R}_{\mathrm{ct}}$ decreased to $188.4 \Omega$ (curve a), which indicates that $\mathrm{Au} / \mathrm{SiO}_{2}$ has an excellent property for electron transport. Introducing $\alpha-\mathrm{CD}$ on $\mathrm{Au} / \mathrm{SiO}_{2}$ leads to an increase of $\mathrm{R}_{\mathrm{ct}}$ to $434.6 \Omega$ (curve b). Finally, the recognition of $\mathrm{RuSD}$ on $\mathrm{Pt} / \mathrm{Au} / \mathrm{SiO}_{2} / \alpha-\mathrm{CD}$ causes a considerable increase in $\mathrm{R}_{\mathrm{ct}}\left(484.3 \Omega\right.$ ) (curve d) because the diffusion of $\left[\mathrm{Fe}(\mathrm{CN})_{6}\right]^{3-/ 4-}$ toward the electrode surface was hindered by the protein layer (dsDNA), which acted as the inert electron and mass-transfer blocking layer.

\subsection{Optimization parameters}

The $\mathrm{pH}$ value can affect the reaction by changing the dissociated state of 
biomolecule and substrate molecule. To achieve an optimal ECL signal, the $\mathrm{pH}$ value of the electrolyte solution was investigated. As shown in Fig. 4A, a maximum value of the ECL intensity was achieved when the $\mathrm{pH}$ value of electrolyte solution was adjusted to 7.5. Considering the survival environment of enzymes in the human body, the neutral surrounding at $\mathrm{pH} 7.5$ was selected as the optimal condition throughout this study. The incubation time is also important in the sensing process. Fig. 4B shows the effect of the incubation time of hOGG 1 on the ECL intensity. The ECL intensity increased with the increase in incubation time from $0.5 \mathrm{~h}$ to $2.5 \mathrm{~h}$. However, the increase in ECL intensity was extremely slow with the increase in incubation time from $2 \mathrm{~h}$ to $2.5 \mathrm{~h}$. Thus, the reaction was basically saturated with the incubation time of $2 \mathrm{~h}$, which was chosen for subsequent experiments.

\subsection{ECL assay of hOGG 1}

Under the optimal assay conditions, the sensitivity of the developed ECL sensor for the assay of hOGG 1 was investigated by varying the hOGG 1 concentrations. As shown in Fig. 5A, the ECL intensity increased with the increase in hOGG 1 concentration, and the ECL intensity versus the hOGG 1 concentration is presented in Fig. 5B. By plotting the ECL intensity with different hOGG 1 concentrations, a work curve that covers the concentration range of 2-200 $\mathrm{U} \mathrm{mL}^{-1}$ was obtained with a linear response of 2-100 $\mathrm{U} \mathrm{mL}^{-1}$. The regression equation was $\mathrm{ECL}=717.60+1317.77 \mathrm{x}$ with a determination coefficient $\left(\mathrm{R}^{2}\right)$ of 0.988 . The limit of detection (LOD) was $0.225 \mathrm{U} \mathrm{mL}^{-1}$ from three times the standard deviation, which corresponded to the blank sample detection $(\mathrm{S} / \mathrm{N}=3)$. The high sensitivity of this method may be attributed 
to the increased electrode area and the host-guest recognition of the $\alpha$-cyclodextrin functionalized $\mathrm{Au} / \mathrm{SiO}_{2}$ core-shell nanoparticles.

\subsection{Specificity, stability and reproducibility}

For many assay methods, some interferents with similar functions or coexisting with the target may inhibit the accurate detection and cause false positive or erroneous detection results. To examine the specificity of the fabricated ECL sensing, interference study was performed using APE 1, T4 PDG and Endo III, which were also important enzymes in the repairing of DNA oxidative damage in the human body. Here, the aforementioned interfering substances with two concentration levels (50 U $\mathrm{mL}^{-1}$ and $500 \mathrm{U} \mathrm{mL}^{-1}$ ) were chosen. The ECL response obtained from the interferents was $36.5 \%-44.7 \%$ of that of hOGG 1 , although their concentrations were 10 times higher than the hOGG 1 concentration (Fig. 6). The result indicates that the fabricated ECL sensing provides adequate specificity to assay hOGG 1 .

The operational stability was a major concern for sensors. Fig. 7 displays the ECL intensity of the ECL sensing under 16 cycles of continuous potential scans between 0.8 and $1.2 \mathrm{~V}$ in $0.1 \mathrm{~mol} \mathrm{~L}^{-1} \mathrm{PBS}(\mathrm{pH} 7.5)$ at $0.1 \mathrm{~V} \mathrm{~s}^{-1}$ to detect $50 \mathrm{U} \mathrm{mL}^{-1}$ of hOGG 1. A strong and stable ECL signal was observed with the RSD of $1.7 \%$. The long-term storage stability of the ECL sensing was also investigated in a 20-day period. When the working electrode was stored at $4{ }^{\circ} \mathrm{C}$ over 10 days, the response current decreased by $2.1 \%$ of its initial response; in the following 10 days, it decreased by $6.1 \%$. It maintained more than $93.9 \%$ of the initial response after storing for 20 days, which demonstrates that the ECL sensing has a good stability with a life 
time of up to 20 days.

The reproducibility of the ECL sensing was investigated by preparing five electrodes to detect $50 \mathrm{U} \mathrm{mL}^{-1}$ of hOGG 1 . The relative standard deviation (RSD) of this measurement was $1.9 \%$. The experimental results demonstrate acceptable reproducibility of the ECL sensing.

\section{Conclusions}

In this work, we developed an ECL sensing based on host-guest recognition for hOGG 1 quantitative analysis. The $\alpha$-cyclodextrin functionalized $\mathrm{Au} / \mathrm{SiO}_{2}$ cell-shell nanoparticles was prepared to enhance the host-guest recognition sensitivity. The ECL emission signal of RuSD was significantly increased using the enhanced host-guest recognition sensitivity. With the amplification of the ECL signal, the ECL sensing showed an enhancement in assay sensitivity and linear range for hOGG 1, whose linear range was 2-100 $\mathrm{U} \mathrm{mL}^{-1}$ with the determination coefficient of 0.988 and detection limit of $0.225 \mathrm{U} \mathrm{mL}^{-1}(\mathrm{~S} / \mathrm{N}=3)$. Moreover, the ECL sensing showed excellent specificity and stability. The effect of $\alpha$-cyclodextrin functionalized $\mathrm{Au} / \mathrm{SiO}_{2}$ cell-shell nanoparticles on amplified signal suggested that this ECL assay was universal, which can be used to other enzymes analysis.

\section{Acknowledgement}

This work was supported by the Research Project of Chinese Ministry of Education (No113017A) and National Natural Science Foundation of China (NSFC-JST 21261140334). Thanks Program for Changjiang Scholars and Innovative Research Team in University (IRT_13R05). 


\section{References}

[1] P.A. Jones, D. Takai, The role of DNA methylation in mammalian epigenetics, Science 293 (2001) 1068-1070.

[2] P.L. McKibbin, A. Kobori, Y. Taniguchi, E.T. Kool, S.S. David, Surprising repair activities of nonpolar analogs of 8-oxoG expose features of recognition and catalysis by base excision repair glycosylases, J. Am. Chem. Soc. 134 (2012) 1653-1661.

[3] R.P. Cunningham, DNA repair: how yeast repairs radical damage, Curr. Biol. 6 (1996) 1230-1233.

[4] Y.S. Lee, H.S. Lee, M.K. Park, E.S. Hwang, E.M. Park, H. Kasai, M.H. Chung, Identification of 8-hydroxyguanine glycosylase activity in mammalian tissues using 8-hydroxyguanine specific monoclonal antibody, Biochem. Bioph. Res. Co. 196 (1993) 1545-1551.

[5] J. Tchou, H. Kasai, S. Shibutani, M.H. Chung, J. Laval, A.P. Grollman, S. Nishimura, 8-Oxoguanine (8-hydroxyguanine) DNA glycosylase and its substrate specificity, PNAS 88 (1991) 4690-4694.

[6] H. Sugimura, T. Kohno, K. Wakai, K. Nagura, K. Genka, H. Igarashi, B.J. Morris, S. Baba, Y. Ohno, C.M. Gao, Z.Y. Li, J.D. Wang, T. Takezaki, K. Tajima, T. Varga, T. Sawaguchi, J.K. Lum, J.J. Martinson, S. Tsugane, T. Iwamasa, K. Shinmura, J. Yokota, hOGG1 Ser326Cys polymorphism and lung cancer susceptibility. Cancer Epidem. Biomar. 8 (1999) 669-674.

[7] Y. Nakabeppu, D. Tsuchimoto, H. Yamaguchi, K. Sakumi, Oxidative damage in nucleic acids and Parkinson's disease, J. Neurosci. Res. 85 (2007) 919-934. 
[8] S. Bashir, G. Harris, M.A. Denman, D.R. Blake, P.G. Winyard, Oxidative DNA damage and cellular sensitivity to oxidative stress in human autoimmune diseases, Ann. Rheum. Dis. 52 (1993) 659-666.

[9] Y. Xiang, Y. Lu, Expanding targets of DNAzyme-based sensors through deactivation and activation of DNAzymes by single uracil removal: sensitive fluorescent assay of uracil-DNA glycosylase, Anal. Chem. 84 (2012) 9981-9987.

[10] A.E. Vidal, I.D. Hickson, S. Boiteux, J.P. Radicella, Mechanism of stimulation of the DNA glycosylase activity of hOGG1 by the major human AP endonuclease: by pass of the AP lyase activity step, Nucleic Acids Res. 29 (2001) 1285-1292.

[11] A. Darwanto, A. Farrel, D.K. Rogstad, L.C. Sowers, Characterization of DNA glycosylase activity by matrix-assisted laser desorption/ionization time-of-flight mass spectrometry, Anal. Biochem. 394 (2009) 13-23.

[12] D. Nikolic, A liquid chromatography-mass spectrometric assay for measuring activity of human 8-oxoguanine-DNA glycosylase, Anal. Biochem. 396 (2010) 275-279.

[13] L. Xia, T.R. O'Connor, DNA glycosylase activity assay based on streptavidin paramagnetic bead substrate capture, Anal. Biochem. 298 (2001) 322-326.

[14] A. Maksimenko, A.A. Ishchenko, G. Sanz, J. Laval, R.H. Elder, M.K. Saparbaev, A molecular beacon assay for measuring base excision repair activities, Biochem. Bioph. Res. Co. 319 (2004) 240-246.

[15] Y. Li, C.C. Huang, J.B. Zheng, H.L. Qi, Electrogenerated chemiluminescence biosensing method for the detection of DNA methylation and assay of the 
methyltransferase activity, Biosens. Bioelectron. 38 (2012) 407-410.

[16] H.S. Yin, Y.L. Zhou, Z.N. Xu, M. Wang, S.Y. Ai, Ultrasensitive electrochemical immunoassay for DNA methyltransferase activity and inhibitor screening based on methyl binding domain protein of $\mathrm{MeCP} 2$ and enzymatic signal amplification, Biosens. Bioelectron. 49 (2013) 39-45.

[17] P. Bujak, P. Bartczak, J. Polanski, Highly efficient room-temperature oxidation of cyclohexene and D-glucose over nanogold $\mathrm{Au} / \mathrm{SiO}_{2}$ in water, J. Catal. 295 (2012) $15-21$.

[18] N.G. Liu, B.S. Prall, V.I. Klimov, Hybrid gold/silica/nanocrystal-quantum-dot superstructures: synthesis and analysis of semiconductor-metal interactions, J. Am. Chem. Soc. 128 (2006) 15362-15363.

[19] T. Ihara, A. Uemura, A. Futamura, M. Shimizu, N. Baba, S. Nishizawa, N. Teramae, A. Jyo, Cooperative DNA probing using a $\beta$-Cyclodextrin-DNA conjugate and a nucleobase-specific fluorescent ligand, J. Am. Chem. Soc. 131 (2009) $1386-1387$.

[20] R. Villalonga, R. Cao, A. Fragoso, Supramolecular chemistry of cyclodextrins in enzyme technology, Chem. Rev. 107 (2007) 3088-3116.

[21] Y. Li, H.L. Qi, F. Fang, C.X. Zhang, Ultrasensitive electyogenerated chemiluminescence detection of DNA hybridization uing carbon-nanotubes loaded with tris (2,2'-bipyridyl) ruthemium derivative tags, Talanta 72 (2007) 1704-1709.

[22] Z. Wu, Z.K. Wu, H. Tang, L.J. Tang, J.H. Jiang, Activity-based DNA-gold nanoparticle probe as colorimetric biosensor for DNA Methyltransferase/Glycosylase 
assay, Anal. Chem. 85 (2013) 4376-4383.

[23] Z. Wu, Z. Zhen, J.H. Jiang, G.L. Shen, R.Q. Yu, Terminal protection of small-molecule-linked DNA for sensitive electrochemical detection of protein binding via selective carbon nanotube assembly, J. Am. Chem. Soc. 131 (2009) 12325-12332. [24] Z. Wu, H.Q. Wang, M. Guo, L.J. Tang, R.Q. Yu, J.H. Jiang, Terminal protection of small molecule-linked DNA: a versatile biosensor platform for protein binding and genetyping assay, Anal. Chem. 83 (2011) 3104-3111.

[25] Y.F. Huang, K.H. Ma, K.B. Kang, M. Zhao, Z.L. Zhang, Y.X. Liu, T. Wen, Q. Wang, W.Y. Qiu, D. Qiu, Core-shell plasmonic nanostructures to fine-tune long “Au nanoparticle-fluorophore" distance and radiative dynamics, Colloid. Surface. A 421 (2013) 101-108.

[26] N.G. Bastús, J. Comenge, V. Puntes, Kinetically controlled seeded growth synthesis of citrate-stabilized gold nanoparticles of up to $200 \mathrm{~nm}$ : size focusing versus ostwald ripening, Langmuir 27 (2011) 11098-11105.

[27] P. Díez, R. Villalonga, M.L. Villalonga, J.M. Pingarrón, Supramolecular immobilization of redox enzymes on cyclodextrin-coated magnetic nanoparticles for biosensing applications, J. Colloid Interf. Sci. 386 (2012) 181-188.

[28] T. Shimdzu, T. Iyoda, K. Izaki, Photoelectrochemical properties of bis (2,2'-bipyridine) (4,4'-dicarboxy-2,2'-bipyridine) ruthenium (II) chloride, J. Phys. Chem. 89 (1985) 642-645.

[29] K. Kalyanasundaram, Md.K. Nazeeruddin, M. Grätzel, G. Viscardi, P. Savarino, E. Barni, Synthesis and photophysical characterization of highly luminescent 
complexes of $\mathrm{Ru}$ (II) containing 4,4'-di-(p-carboxyphenyl)-2,2'-bipyridine, Inorg. Chim. Acta. 198-200 (1992) 831-839.

[30] R.F. Khairoutdinov, L.V. Doubova, R.C. Haddon, L. Saraf, Persistent photoconductivity in chemically modified single-wall carbon nanotubes, J. Phys. Chem. B 108 (2004) 19976-19981.

[31] F. Frehill, J.G. Vos, S. Benrezzak, A.A. Koós, Z. Kónya, M.G. Rüther, W.J. Blau, A. Fonseca, J.B. Nagy, L.P. Biró, A.I. Minett, M. in het Panhuis, Interconnecting carbon nanotubes with an inorganic metal complex, J. Am. Chem. Soc. 124 (2002) 13694-13695.

[32] J. Wang, G. Liu, M.R. Jan, Ultrasensitive Electrical Biosensing of Proteins and DNA: Carbon-Nanotube Derived Amplification of the Recognition and Transduction Events, J. Am. Chem. Soc. 126 (2004) 3010-3011.

[33] W. Pluemsab, N. Sakairi, T. Furuike, Synthesis and inclusion property of $\alpha$-cyclodextrin-linked alginate, Polymer 46 (2005) 9778-9783.

[34] M.C. Wei, D. Tian, S. Liu, X.L. Zheng, S. Duan, C.L. Zhou, $\beta$-Cyclodextrin functionalized graphene material: a novelelectrochemical sensor for simultaneous determination of 2-chlorophenol and 3-chlorophenol, Sensor. Actuat. B-Chem. 195 (2014) 452-458.

[35] A.Z.M. Badruddoza, K. Hidajat, M.S. Uddin, Synthesis and characterization of $\beta$-cyclodextrin-conjugated magnetic nanoparticles and their uses as solid-phase artificial chaperones in refolding of carbonic anhydrase bovine, J. Colloid Interf. Sci. 346 (2010) 337-346. 
[36] W. Li, B.L. Zhang, X.J. Li, H.P. Zhang, Q.Y. Zhang, Preparation and characterization of novel immobilized $\mathrm{Fe}_{3} \mathrm{O}_{4} @ \mathrm{SiO}_{2} @ \mathrm{mSiO}_{2}-\mathrm{Pd}(0)$ catalyst with large pore-size mesoporous for Suzuki coupling reaction, Appl. Catal. A-Gen. 459 (2013) 65-72.

[37] J. Zhang, H.L. Qi, Y. Li, J. Yang, Q. Gao, C.X. Zhang, Electrogenerated chemiluminescence DNA biosensor based on hairpin DNA probe labeled with ruthenium complex, Anal. Chem. 80 (2008) 2888-2894.

[38] F. Xiao, Y.Q. Li, X.L. Zan, K. Liao, R. Xu, H.W. Duan, Growth of metal-metal oxide nanostructures on freestanding graphene paper for flexible biosensors, Adv. Funct. Mater. 12 (2012) 2487-2494.

[39] Y. Qian, C.Y. Wang, F.L. Gao, Enzyme-free amplification for sensitive electrochemical detection of DNA via target-catalyzed hairpin assembly assisted current change, Talanta130 (2014) 33-38. 


\section{Figure captions}

Scheme 1. Schematic representation of enhanced host-guest recognition technique -based ECL sensor strategy.

Scheme 2. Schematic illustration of the preparation procedure of $\alpha$-cyclodextrin functionalized $\mathrm{Au} / \mathrm{SiO}_{2}$ core-shell nanoparticles.

Scheme 3. Schematic illustration of the preparation processes of the ECL electrode.

Fig. 1. (A) FT-IR spectra of $6-\mathrm{TsO}-\alpha-\mathrm{CD}$ (curve a), $\mathrm{Au} / \mathrm{SiO}_{2}$ (curve b) and $\mathrm{Au} / \mathrm{SiO}_{2} / \alpha-\mathrm{CD}$ (curve c) core-shell nanoparticles. (B) TEM images of $\mathrm{Au} / \mathrm{SiO}_{2}$ core-shell nanoparticles. (C) TEM images of $\mathrm{Au} / \mathrm{SiO}_{2} / \alpha-\mathrm{CD}$ (curve c) core-shell nanoparticles.

Fig. 2. (A) UV/vis absorption spectra of SWNTs (curve a), dabcyl-labeled dsDNA (curve b), Ru(bpy)2(dcbpy)NHS (curve c) and RuSD (curve d). (B) TEM images of SWNTs. (C) TEM images of RuSD.

Fig. 3. (A) The ECL signals of bare Pt electrode (curve a), Pt/a-CD (curve b), $\mathrm{Pt} / \mathrm{Au} / \mathrm{SiO}_{2} / \alpha-\mathrm{CD}$ (curve c), $\mathrm{Pt} / \alpha-\mathrm{CD} / \mathrm{RuSD}$ (curve d) and $\mathrm{Pt} / \mathrm{Au} / \mathrm{SiO}_{2} / \alpha-\mathrm{CD} / \mathrm{RuSD}$ (curve e) in $0.1 \mathrm{~mol} \mathrm{~L}^{-1} \mathrm{PBS}$ solution ( $\mathrm{pH} 7.5$ ) containing $0.1 \mathrm{~mol} \mathrm{~L}^{-1} \mathrm{TPrA}$. Scan rate, $0.1 \mathrm{~V} \mathrm{~s}^{-1}$. The voltage of PMT was $600 \mathrm{~V}$. Inset: Enlarge figure of curve a, b and c. (B) EIS of $\mathrm{Pt} / \mathrm{Au} / \mathrm{SiO}_{2}$ (curve a), $\mathrm{Pt} / \mathrm{Au} / \mathrm{SiO}_{2} / \alpha-\mathrm{CD}$ (curve b), bare $\mathrm{Pt}$ electrode (curve c) and $\mathrm{Pt} / \mathrm{Au} / \mathrm{SiO}_{2} / \alpha-\mathrm{CD} / \mathrm{RuSD}$ (curve d) in $0.1 \mathrm{~mol} \mathrm{~L}^{-1} \mathrm{PBS}$ (pH 7.5) containing 0.005 mol $\mathrm{L}^{-1}\left[\mathrm{Fe}(\mathrm{CN})_{6}\right]^{-3 /-4}$. The frequency range is between 0.1 and $1,000,000 \mathrm{~Hz}$ with signal amplitude of 0V. Inset: the equivalent circuit.

Fig. 4. (A) Effects of $\mathrm{pH}$ value of electrolyte solution and (B) incubation time of 
hOGG 1 on the response of ECL sensing for the detection of $50 \mathrm{U} \mathrm{mL}^{-1}$ hOGG $1(\mathrm{n}=$ 3) in $0.1 \mathrm{~mol} \mathrm{~L}^{-1} \mathrm{PBS}$ solution (pH 7.5) containing $0.1 \mathrm{~mol} \mathrm{~L}^{-1} \mathrm{TPrA}$. Scan rate, $0.1 \mathrm{~V}$ $\mathrm{s}^{-1}$. The voltage of PMT was $600 \mathrm{~V}$.

Fig. 5. (A) ECL responses of the proposed ECL sensing to different concentrations of hOGG 1 (U mL $\left.{ }^{-1}\right)$ : (a) 0, (b) 2, (c) 5, (d) 10, (e) 20, (f) 50, (g) 100 and (h) 200 in $0.1 \mathrm{~mol} \mathrm{~L}{ }^{-1}$ PBS solution ( $\mathrm{pH} 7.5$ ) containing $0.1 \mathrm{~mol} \mathrm{~L}^{-1} \mathrm{TPrA}$. Scan rate, $0.1 \mathrm{~V} \mathrm{~s}^{-1}$. The voltage of PMT was 600 V. (B) The calibration curve for hOGG 1 assay $(n=3)$.

Fig. 6. The selectivity of the proposed ECL sensing of hOGG 1, APE 1, T4 PDG and Endo III at concentration of $50 \mathrm{U} \mathrm{mL}^{-1}$, respectively $(\mathrm{n}=3)$. All measurements were performed in $0.1 \mathrm{~mol} \mathrm{~L}^{-1} \mathrm{PBS}$ solution ( $\mathrm{pH} 7.5$ ) containing $0.1 \mathrm{~mol} \mathrm{~L}{ }^{-1} \mathrm{TPrA}$. Scan rate, $0.1 \mathrm{~V} \mathrm{~s}^{-1}$. The voltage of PMT was $600 \mathrm{~V}$.

Fig. 7. The ECL intensities of sixteen consecutive cycles of the proposed ECL sensing incubated with $50 \mathrm{U} \mathrm{mL}^{-1}$ hOGG 1 in $0.1 \mathrm{~mol} \mathrm{~L}^{-1} \mathrm{PBS}$ solution $(\mathrm{pH} 7.5)$ containing $0.1 \mathrm{~mol} \mathrm{~L}^{-1}$ TPrA. Scan rate, $0.1 \mathrm{~V} \mathrm{~s}^{-1}$. The voltage of PMT was $600 \mathrm{~V}$. 
Fig. 1.
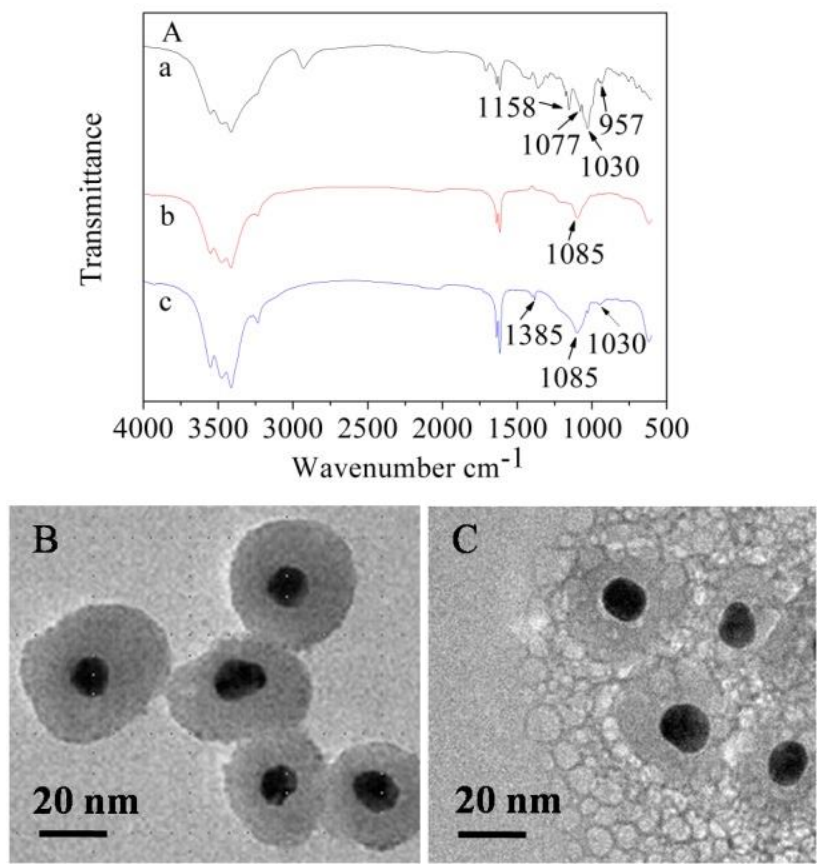
Fig. 2.
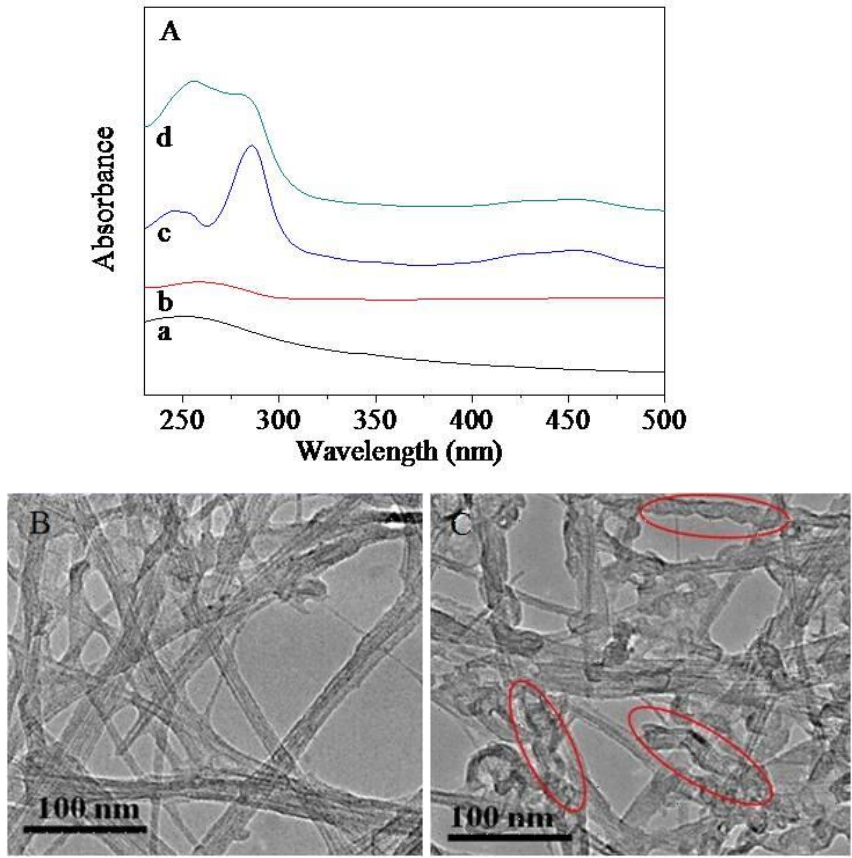
Fig. 3.
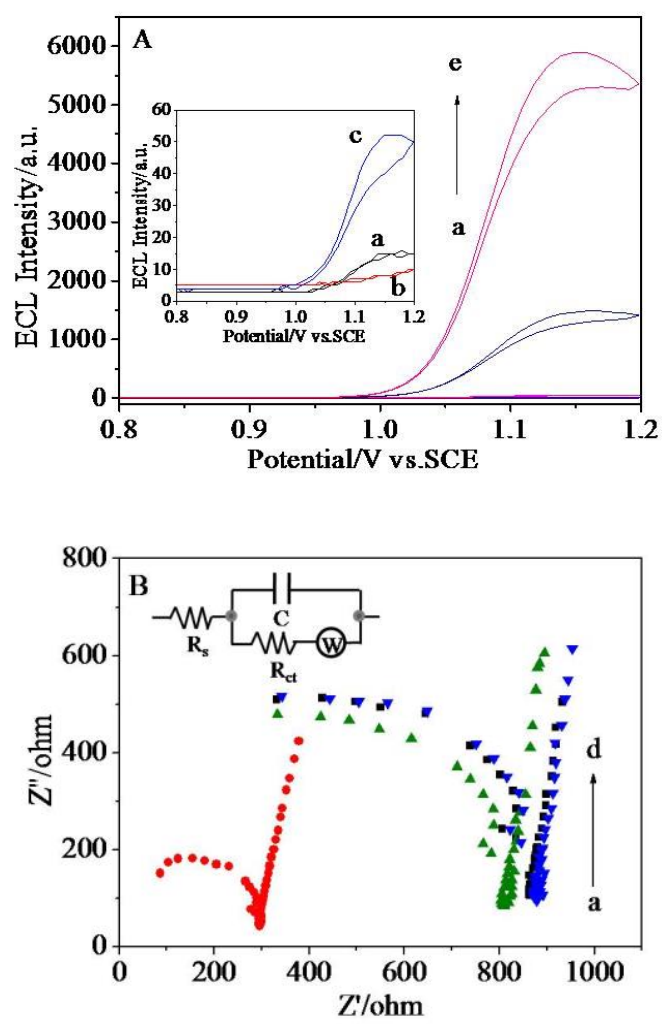
Fig. 4.
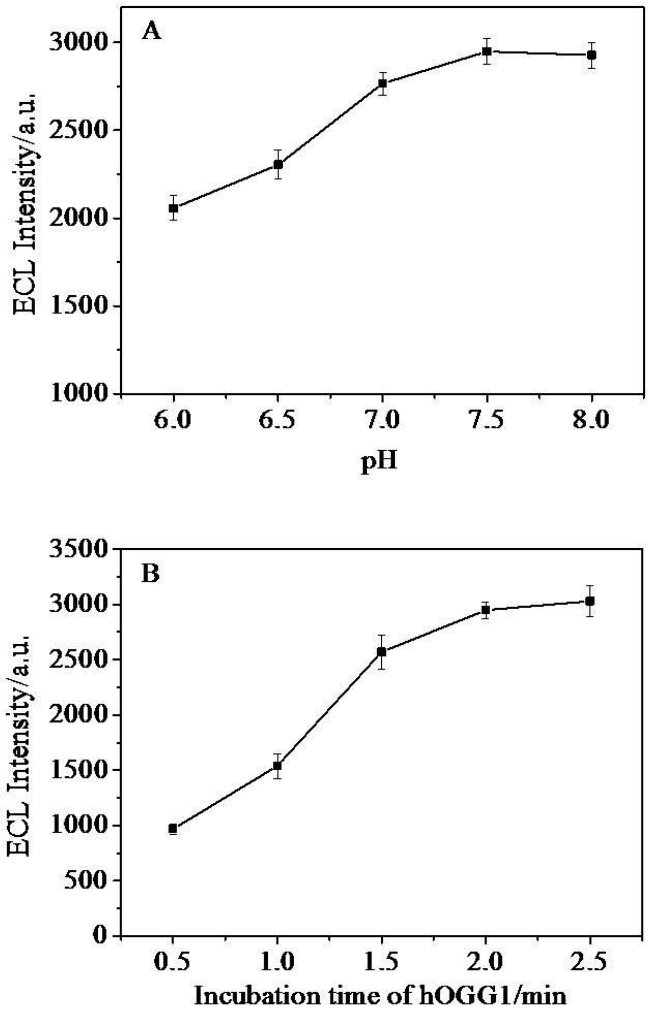
Fig. 5.
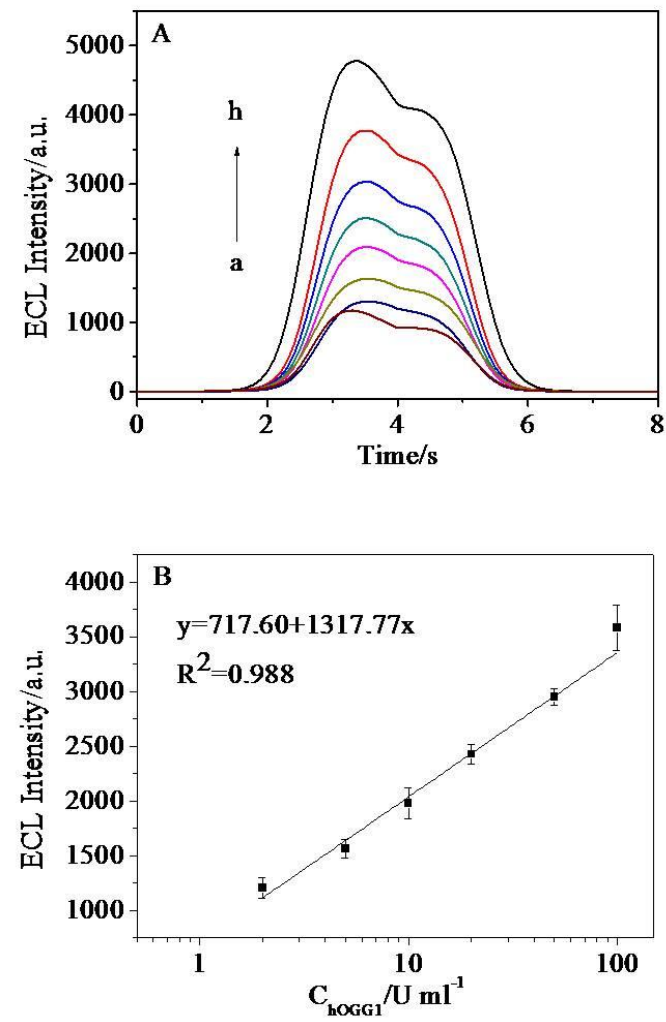
Fig. 6.

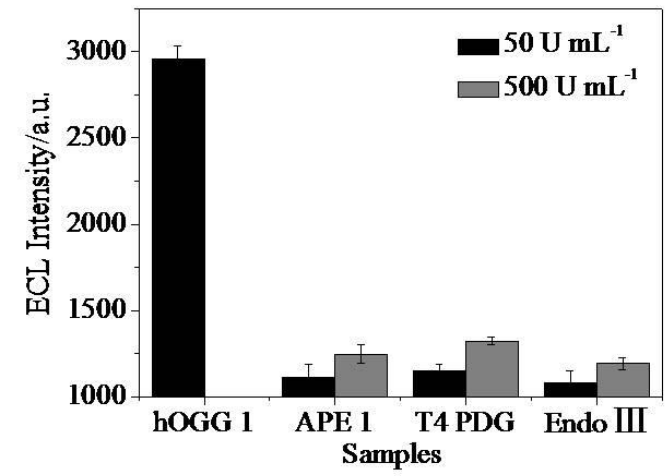


Fig. 7.

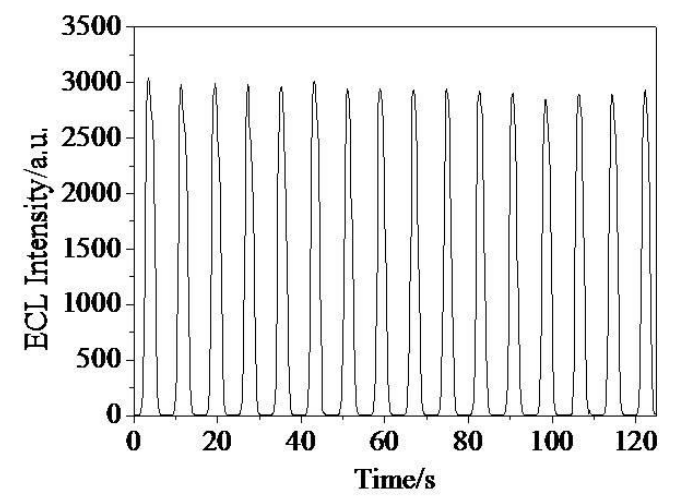

